\title{
Implications of the cut type and apex length of stem cuttings used for the production of plantlets of Conilon coffee
}

\author{
Abraão Carlos Verdin Filho1 (iD), Silvio de Jesus Freitas ${ }^{2}$ (D), Marcone Comério1 (iD), Paulo Sérgio Volpi ${ }^{1}$ (D), Tafarel Victor Colodetti ${ }^{3}$ (D), \\ Wagner Nunes Rodrigues ${ }^{3}$ (i) Aymbiré Francisco Almeida da Fonseca $^{4}$ (D), Sheila Cristina Pruculi Posse ${ }^{5}$ (D), \\ Alexandre Gomes Fontes $^{6}$ (D), Bruno Fardim Christo ${ }^{3}$ (D), Luciano Junior Dias Vieira1 (iD)
}

\author{
${ }^{1}$ Instituto Capixaba de Pesquisa, Assistência Técnica e Extensão Rural/INCAPER, Marilândia, ES, Brasil \\ ${ }^{2}$ Universidade Estadual do Norte Fluminense/UENF, Campos dos Goytacazes, RJ, Brasil \\ ${ }^{3}$ Universidade Federal do Espírito Santo/UFES, Centro de Ciências Agrárias e Engenharias/CCAE, Alegre, ES, Brasil \\ ${ }^{4}$ Empresa Brasileira de Pesquisa Agropecuária/EMBRAPA, Embrapa Café, Vitória, ES, Brasil \\ 5 Instituto Capixaba de Pesquisa, Assistência Técnica e Extensão Rural/INCAPER, Vitória, ES, Brasil \\ ${ }^{6}$ Instituto Federal do Espírito Santo/IFES, Colatina, ES, Brasil \\ Contact authors: verdin.incaper@gmail.com,freitassj@yahoo.com.br, marcone.comerio@incaper.es.gov.br, paulovolpi@incaper.es.gov.br, tafarelcolodetti@hotmail.com, \\ wagnernunes@outlook.com, aymbire.fonseca@embrapa.br, sheilaposse@incaper.es.gov.br, alexandre.fontes@ifes.edu.br, brunochristo@hotmail.com, lucianojuniordiasvieira@gmail.com \\ Received in March 13, 2020 and approved in November 18, 2020
}

\section{ABSTRACT}

Producing plantlets of Conilon coffee within the specific recommendations and with a high level of quality is fundamental since it is capable of promoting the initial development of the crops. To identify the best protocol to prepare the stem cuttings is fundamental to the process of plantlet production of the species. In this context, this study aimed to evaluate the implications of the type of apex cutting and the length of the remaining apex of stem cuttings to produce plantlets of Conilon coffee (Coffea canephora). To this end, two trials were conducted in the Marilândia Experimental Farm (Instituto Capixaba de Pesquisa, Assistência Técnica e Extensão Rural, Marilândia-ES). The first trial evaluated the types of apex cutting (straight or bevel cut), and the second trial studied the different lengths of the remaining apex $(0.5,1.0,1.5,2.0$, and $2.5 \mathrm{~cm})$. Characteristics of the vegetative growth and photosynthetic traits of the plantlets of Conilon coffee were evaluated after 120 days of cultivation in a nursery. The biomass accumulation of the plantlets of Conilon coffee produced by stem cutting may be favored by the use of bevel cut on the apex. The length of the remaining apex does not seem to have a expressive effect over the quality or growth of the plantlets, being only possible to observe effects for leaf area and biomass accumulation.

Index terms: Asexual propagation; Cloning; Coffea canephora; Photosynthesis; Quality.

\section{INTRODUCTION}

Conilon coffee (Coffea canephora Pierre ex A. Froehner) is a species that has enormous importance for agricultural activities in Brazil and, especially, for the economy of the state of Espírito Santo, as it is the largest producer of Conilon coffee in the country (Belan et al., 2011; Bernardes et al., 2012; Covre et al., 2013).

There is a considerable area of coffee plantation being annually renewed; in this context, there is a growing demand for coffee plantlets. Since 2013, it is estimated that approximately 110 million plantlets of Conilon coffee were produced in Brazil, of which only about $10 \%$ originated from seeds (Mauri et al., 2015).

Due to a mechanism of gametophytic selfincompatibility, the Conilon coffee is a species of allogamous reproduction. A factor that leads to the formation of heterogeneous populations for traits such as plant height, vigor, season and maturity uniformity of fruits, shape, size, and weight of grains, susceptibility to pests and diseases, tolerance to drought and, especially, productive potential (Conagin; Mendes, 1961; Van Der Vossen, 1985; Carvalho et al., 1991; Carvalho; Fazuoli, 1993; Covre et al., 2013; Rocha et al., 2014; Ferrão et al., 2019).
The technique used to obtain uniform plants for crops of Conilon coffee is the asexual propagation, manly performed by the stem cutting method, which consists in cutting segments of orthotropic stems originated from serial buds, retaining a pair of leaves and two plagiotropic branches (Paulino; Matiello; Paulini, 1985; Bragança et al., 1995; Ferrão et al., 2007; Paiva et al., 2012; Partelli et al., 2014; Fonseca et al., 2019).

There are several advantages of using the propagation by stem cuttings compared to the use of seedlings (multiplication by coffee seeds), such as the faster formation of the plant canopy, higher crop uniformity, easier handling of pruning, precocity of production, higher crop yield, among others (Espindula; Partelli, 2011; Fonseca et al., 2019).

In this context, to produce plantlets within the specific recommendations and with a high level of quality is fundamental, since its capable of promoting the initial development of the crops, as well as higher possible yield. Even if there have been significant advances in the cultivation of Conilon coffee and broad utilization of the technology of rooting stem cuttings, there are still different pieces of information to be elucidated about the asexual propagation of this species.

Paulino, Matiello and Paulini (1985) presented the first works detailing the processes involved in the production of clonal plantlets by cutting plagiotropic branches, mainly 
concerning the preparation of the clonal cutting. Until recently, it was recommended a bevel cut on the base of the stem cutting to induce a rapid rhizogenesis (Fonseca et al., 2005). However, a study executed by Verdin Filho et al (2014) for Conilon coffee revealed that modifying this traditional bevel to a straight cut, in the base of the stem cutting, resulted in a higher quality of the plantlets.

To refine the process of preparing stem cuttings is a strategy to improve the quality of plantlets of Conilon coffee and ensure the formation of more productive crops. Thus, it is necessary to expand the studies on such processes used in the asexual multiplication of the species. In this context, this study aimed to evaluate the implications of the cut type and the length of the remaining apex of stem cuttings of Conilon coffee over the growth and physiology of plantlets.

\section{MATERIAL AND METHODS}

\subsection{Experimental design}

Two trials were conducted in the Marilândia Experimental Farm (Fazenda Experimental de Marilância, FEM), an agricultural research base managed by INCAPER (Instituto Capixaba de Pesquisa, Assistência Técnica e Extensão Rural), located in the municipality of Marilândia, Northwest Region of Espírito Santo State, Southeast Region of Brazil, at the geographic coordinates 19'24'26.09'S and $40^{\circ} 32$ '26.83' W, and altitude of $89 \mathrm{~m}$ above sea level. The trials were carried out concurrently and executed in a nursery for the production of Conilon coffee plantlets, covered by a polyethylene screen to promote the level of $50 \%$ of shade, under controlled conditions. The cultivar used in the trials was the clonal cultivar "Vitória Incaper 8142".

The first trial followed a completely randomized design, with two treatments referring to the cut type (straight or bevel cut), tested using 15 repetitions and experimental plots composed of four plantlets. The second trial also followed a completely randomized design, testing five treatments referring to the lengths of the remaining apex of the stem cutting $(0.5,1.0,1.5$, 2.0 , and $2.5 \mathrm{~cm}$ from the insertion of the plagiotropic branches), using 15 repetitions and four plantlets per experimental plot.

\subsection{Production of plantlets}

Well-developed shoots were collected randomly from adult parent-plants from the cultivar "Vitória Incaper 8142" grown in a clonal garden, cultivated with the technique of bending orthotropic branches to stimulate the emission of shoots. The matrix-plants were standardized regarding age, nutritional, and phytosanitary aspects.

The clonal cuttings were extracted from the central part of the shoots, discarding the basal and apex regions of the stems, since these regions are excessively lignified (base) or soft (apex). In the preparation of the cuttings for the first trial, the type of apex cut was changed in the two treatments (Figure 1). For the second trial, the length for the apex of the stem cuttings was altered to $0.5 ; 1.0 ; 1.5,2.0$, and $2.5 \mathrm{~cm}$ from the insertion of the pair of plagiotropic branches, wherein this case, it was used the bevel cut (Figure 2). For both trials, the base was standardized at $4 \mathrm{~cm}$ of length using a straight cut on the lower end (Verdin Filho et al., 2014), as well as leaving a pair of leaves per stem cutting, which were cut of about a third of its original area. The remaining stages of the propagation by stem cutting for Conilon coffee plantlets followed the recommendations of Fonseca et al. (2019).

After preparing, the stem cuttings had $2 / 3$ of their length buried, in a vertical position, in plastic tubes (tubets) with a volume of $280 \mathrm{~cm}^{3}$, using a mixture with $70 \%$ commercial substrate and $30 \%$ coffee husk obtained from the processing of coffee harvested during the previous year (Verdin Filho et al., 2018). The plantlets were cultivated in a nursery along 120 days, and their nutrition, irrigation, and phytosanitary management were carried out according to the recommendations to produce plantlets of Conilon coffee of Ferrão et al. (2012) and Fonseca et al. (2019).
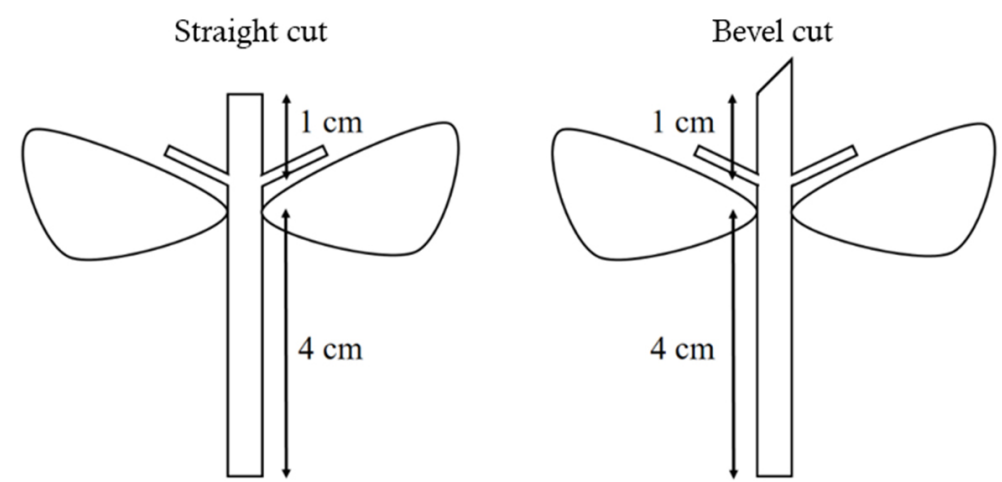

Figure 1: Illustrative scheme of the types of cutting (straight and bevel) at the apex of the stem cuttings adopted in the first trial and demonstration of the starting point for the measurements of the apex length $(1 \mathrm{~cm})$ and base length $(4 \mathrm{~cm})$ of stem cuttings of Conilon coffee, as well as the straight cut used at the base of the cuttings. 


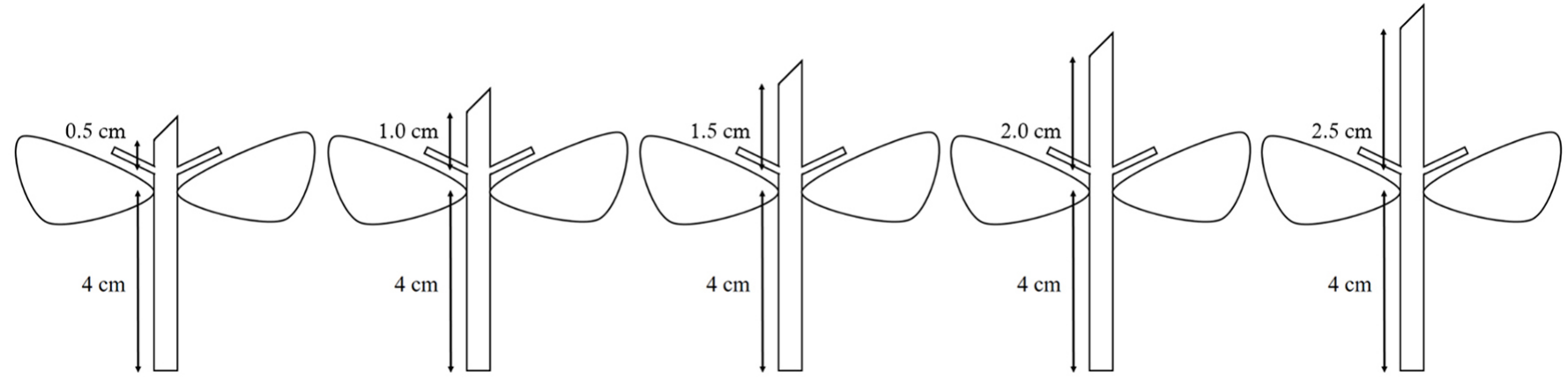

Figure 2: Illustratives cheme for representing the remaining length of the apex $(0.5,1.0,1.5,2.0$, and $2.5 \mathrm{~cm})$ and base $(4 \mathrm{~cm})$ of the stem cuttings of Conilon coffee adopted in the second trial, as well as the straight cut used at the base of the cuttings.

\subsection{Evaluations}

After 120 days of cultivation, the plantlets from the first trial were evaluated regarding the growth parameters: height of plantlet (HGT), using a graduated ruler; stem diameter (DIA), using a digital caliper; leaf area of the plantlet (TLA), obtained by the non-destructive method of linear dimensions (Barros et al., 1973; Brinate et al., 2015). For the physiological parameters, in the first completely expanded pair of leaves from the apex, it was evaluated the gas exchange rate, using a portable infrared gas analyzer (Licor, IRGA 6400XT), between 9:00-11:00 am on sunny days. An irradiance of 1,000 PAR and a $\mathrm{CO}_{2}$ concentration of $400 \mathrm{ppm}$ were used. The net assimilation rate of $\mathrm{CO}_{2}(A)$ and the transpiration rate $(E)$ were evaluated. In these same leaves and at the same time, the total chlorophyll content $(\mathrm{CHL})$ was obtained using a portable chlorophyll-o-meter (Falker, ClorofiLOG FL1030).

After these analyses, the plantlets were collected, separated into stems, leaves, and roots, adequately identified, and dried in a forced-air circulation oven at $65^{\circ} \mathrm{C} \pm 2{ }^{\circ} \mathrm{C}$ until a constant mass was obtained and later weighed on a precision electronic scale (precision of $0.0001 \mathrm{~g}$ ). The total dry matter of plantlets (TDM) was obtained by adding the leaves dry mass (LDM), stems dry mass (SDM), and roots dry mass (MSR). The Dickson's quality index (DQI) was calculated following the method proposed by Dickson et al. (1960), through the equation: $\mathrm{DQI}=$ [total dry matter/(RHD+RAR $)]$, where RHD represents the ratio between the height of plantlet and its stem diameter; and RAR is the ratio between the mass of the aerial part and the mass of the root system.

The plantlets from the second trial were evaluated after 120 days of cultivation, regarding the following variables: height of plantlet (HGT); stem diameter (DIA); leaf area of the plantlet (TLA); net assimilation rate of $\mathrm{CO}_{2}$ $(A)$; transpiration rate $(E)$; total chlorophyll content (CHL); leaves dry mass (LDM); stems dry mass (SDM); and roots dry mass (MSR); total dry matter of plantlets (TDM) and Dickson's quality index (DQI), following the same methods proposed in the first trial.
In addition to these variables, the following parameters were analyzed: leaf mass ratio (LMR), obtained by the ratio between LDM and TDM; stem mass ratio (SMR), obtained by the ratio between SDM and TDM; root mass ratio (RMR), obtained as the ratio between RDM and TDM; leaf area ratio (LAR), obtained as the relationship between TLA and LDM; and the intercellular concentration of $\mathrm{CO}_{2}\left(\mathrm{C}_{\mathrm{i}}\right)$ was obtained during the gas exchange analyses.

\subsection{Statistical analysis}

The data were subjected to the assumptions of normality and homogeneity, followed by the analysis of variance (ANAVA). For the types of cutting on the apex of the stem cuttings, the qualitative data were compared using the Tukey test $(p \leq 0.05)$. For the length of the apex of the stem cutting, the quantitative data were subjected to regression analysis $(\mathrm{p} \leq 0.05)$, using the statistical software SISVAR version 5.6 (Ferreira, 2011).

\section{RESULTS}

\subsection{Trial 1 - Implications of the cut type on the apex of the stem cutting of Conilon coffee}

There was no statistical differentiation for the analyzed variables, except for LDM, SDM, and TDM, for which higher means were verified from plantlets produced using the bevel cut at the apex (Figure 3).

In this study, cuttings with a bevel cut at the apex showed an increase of $17.8 \%$ in the total biomass (TDM). Since the DQI considers the vegetative vigor and the distribution pattern of biomass in the plantlet, it is possible that with the advancing age, there may be a tendency of superiority for the variable in plantlets whose cuttings have a bevel cut at the apex compared to those with a straight cut, even though there was no significant difference of this variable at the evaluated age. 

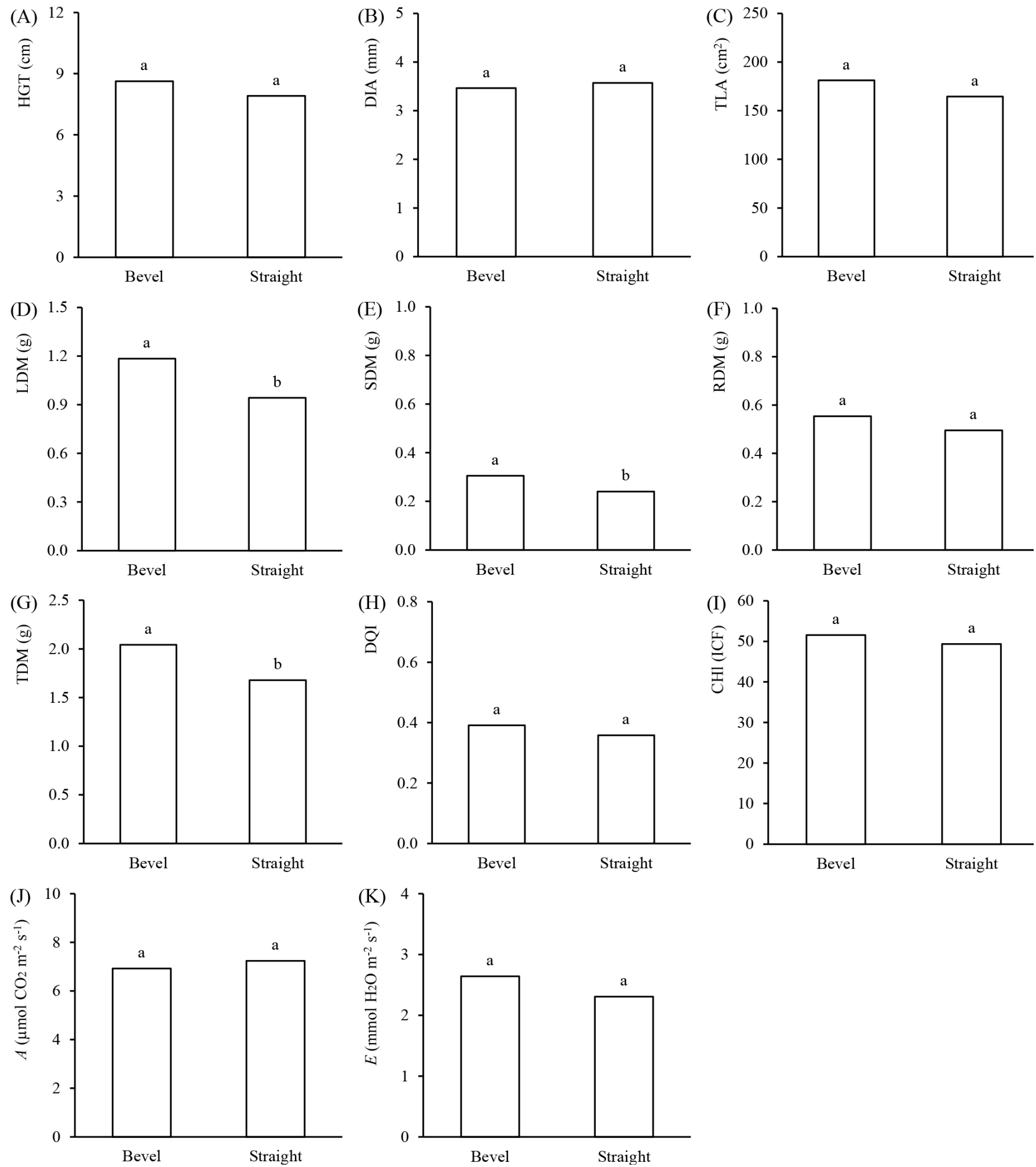

Figure 3: Height of plantlet $(A)$, stem diameter $(B)$, total leaf area $(C)$, leaf dry mass $(D)$, stem dry mass $(E)$, root dry mass $(F)$, total dry matter $(\mathrm{G})$, Dickson's quality index $(\mathrm{H})$, total chlorophyll content $(\mathrm{I})$, net assimilation rate of $\mathrm{CO}_{2}(\mathrm{~J})$ and transpiration rate (K) of plantlets of Conilon coffee produced using stem cuttings, at 120 days of cultivation, as a function of the cut type of the apex of the stem cutting, produced in Marilância-ES (means followed by the same letter in the comparison between bars do not differ by Tukey's test, at $5 \%$ of probability). 
In general, the bevel cut at the apex of the stem cuttings was statistically similar to the results obtained using the straight cut, however, with a better result of biomass accumulation. Therefore, the bevel cut at the apex may be indicated for the production of clonal plantlets.

\subsection{Trial 2 - Implications of the length of the apex of the stem cutting of Conilon coffee}

For the growth variables, there was no significant effect $(\mathrm{p} \leq 0.05)$ of the treatments, except for TLA and TDM (Figures $4 \mathrm{C}$ and 4D). As for HGT and DIA, there was no significant difference as a function of the length of the apex of the stem cutting, with average values of $9.17 \mathrm{~cm}$ and $3.60 \mathrm{~mm}$, respectively (Figures $4 \mathrm{~A}$ and $4 \mathrm{~B}$ ).

Regarding TLA, there was a difference with quadratic adjustment to the linear regression model, in which there was a tendency to increase the leaf area up to the apex length equal to $1.53 \mathrm{~cm}$, obtaining a maximum expansion of $226.33 \mathrm{~cm}^{2}$ (Figure 4C). From that length, there was a decrease in TLA.
The same occurred for TDM, in which the most significant accumulation of dry mass $(2.18 \mathrm{~g})$ was found at the apex length of $1.61 \mathrm{~cm}$, as estimated by the quadratic adjustment of the linear regression (Figure 4D).

The proportion of biomass allocated in the different vegetative organs of the plant was not altered by the length of the apex of the stem cuttings. Of the total biomass accumulated, $56.57 \%$ was allocated to leaves (RMF), $15.11 \%$ to stem (RMC), and $28.32 \%$ to roots (RMR) (Figures $4 \mathrm{E}, 4 \mathrm{~F}$, and $4 \mathrm{G}$, respectively). There was also no change in the expansion of leaf tissue per unit of dry mass of the plantlets, with an average of $99.60 \mathrm{~cm}^{2}$ of leaf tissue formed per gram of dry biomass produced (Figure $4 \mathrm{H}$ ).

Regarding the DQI, there was no variation due to the apex lengths of stem cuttings, with an average quality index of 0.40 (Figure 4I). However, it is suggested that better quality of plantlets may be obtained when the cuttings are prepared keeping the apex around 1.53 and $1.61 \mathrm{~cm}$ in length, due to the larger leaf area and higher accumulation of biomass observed in these lengths (respectivelly) being favorable after the period evaluated in this study.
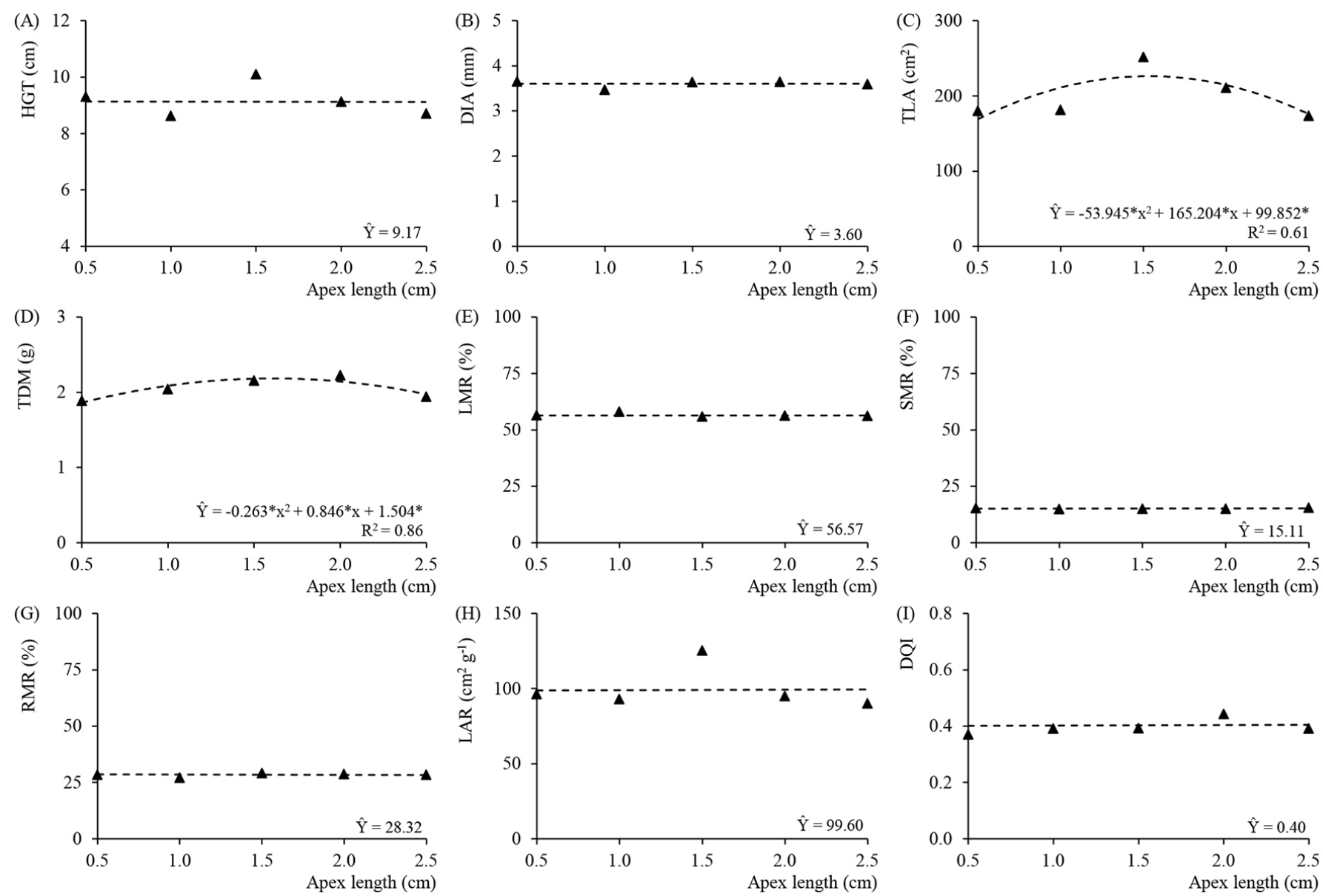

Figure 4: Height of plantlet $(A)$, stem diameter $(B)$, total leaf area $(C)$, total dry matter $(D)$, leaf mass ratio $(E)$, stem mass ratio $(F)$, root mass ratio $(G)$, leaf area ratio $(H)$ and Dickson's quality index $(I)$ of clonal plantlets of Conilon coffee produced using stem cuttings, at 120 days of cultivation, as a function of the length of the apex of the stem cutting, produced in Marilância-ES ('regression coefficient is significant, at $5 \%$ of probability, by the t-test). 
For the physiological traits, there was no influence of the treatments over the chlorophyll content of the plantlets, net photosynthetic rate, transpiration rate, and intercellular concentration of $\mathrm{CO}_{2}$, which resulted in averages of $50.65 \mathrm{ICF}$ (Figure 5A), $6.87 \mu \mathrm{mol} \mathrm{CO} \mathrm{m}^{-2} \mathrm{~s}^{-1}$ (Figure 5B), $2.35 \mathrm{mmol}$ $\mathrm{H}_{2} \mathrm{O} \mathrm{m}^{-2} \mathrm{~s}^{-1}$ (Figure 5C), and $280.91 \mu \mathrm{mol} \mathrm{CO} \mathrm{mol}^{-1}$ (Figure 5D), respectively.

\section{DISCUSSION}

The accumulation of dry mass is a robust property to complement the growth assessment of plant species (Paiva et al., 2010; Covre et al., 2013). According to Dardengo et al. (2013), the total dry matter and the stem diameter are the most favorable variables to indicate the quality of young plants of Conilon coffee.

The TDM values observed in this study were higher than those found by Aquino et al. (2017), while studying the production of clonal plantlets by the cutting method in Conilon coffee. Verdin Filho et al. (2014) found a higher TDM in Conilon coffee by using a straight cut at the base of the stem cuttings, which favored the development of the root system and, consequently, of the seedling as a whole. This result corroborates the hypothesis that different types of cut, either at the base or at the apex of the clonal cut, may influence the development of plantlets of Conilon coffee.
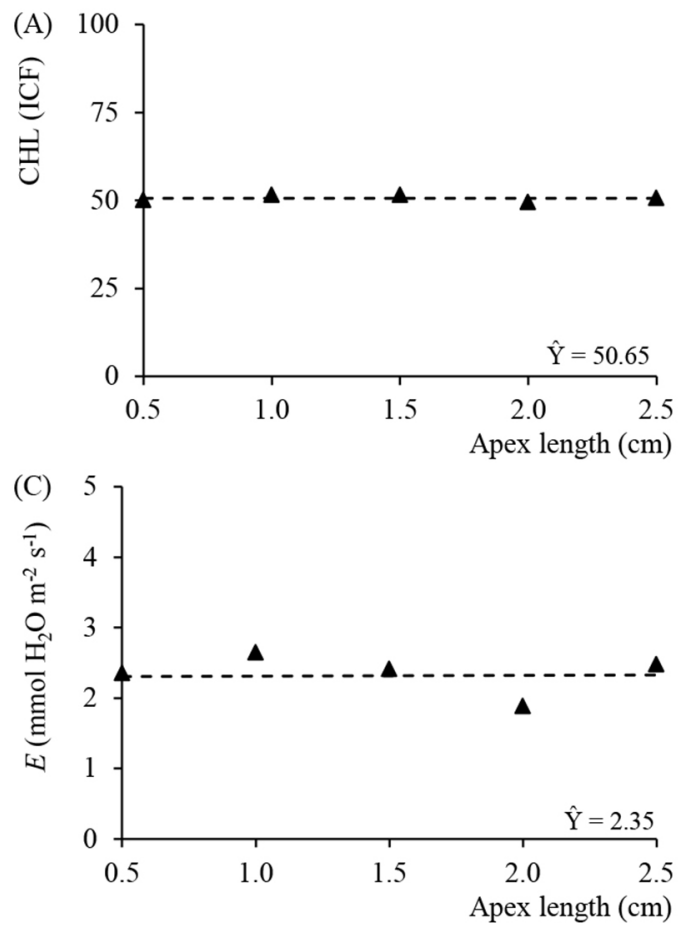

It was also observed that the bevel cut could promote a lower incidence of phytosanitary problems by favoring the flow of water from the apex of the cuttings, while the straight cut may favor the accumulation. The higher abundance of water at the apex of the cuttings, caused by irrigation, can lead to the occurrence of tissue rot in contact with atmospheric air. Fungi such as Fusarium xylarioides, indicated as the etiologic agent of "tracheomycosis" or vascular wilting of Coffee trees (Steyaert, 1948), can be established under these conditions. The fungus invades the vascular system and, after a short incubation period, causes wilt and, finally, the death of the plant (Blittersdorff; Kranz, 1976). It is transmitted by air through ascospores and conidia. The ascogenic phase is known as Gibberella xylarioides (Booth; Waterston, 1964).

The length of the cut is a factor of great importance for the survival, rooting, and emission of sprouts of the plantlet since it is related to the amount of carbohydrates and endogenous auxins reserved in the tissues (Pontes Filho et al., 2014). Short cuttings may not have enough reserves to meet the energy demands of the rhizogenesis, while excessively long cuttings may become more susceptible to dehydration due to the large surface exposed to the environment and the greater demand for water to keep the most substantial amount of tissue alive (Braga et al., 2006; Lima et al., 2006). The dehydration that may occur in long cuttings is due to the orthotropic branches, still young, not being covered by a thick cuticle (Albiero et al., 2005), not making an anatomical defense against dehydration (Carvalho et al., 2001; Taiz; Zeiger, 2013).
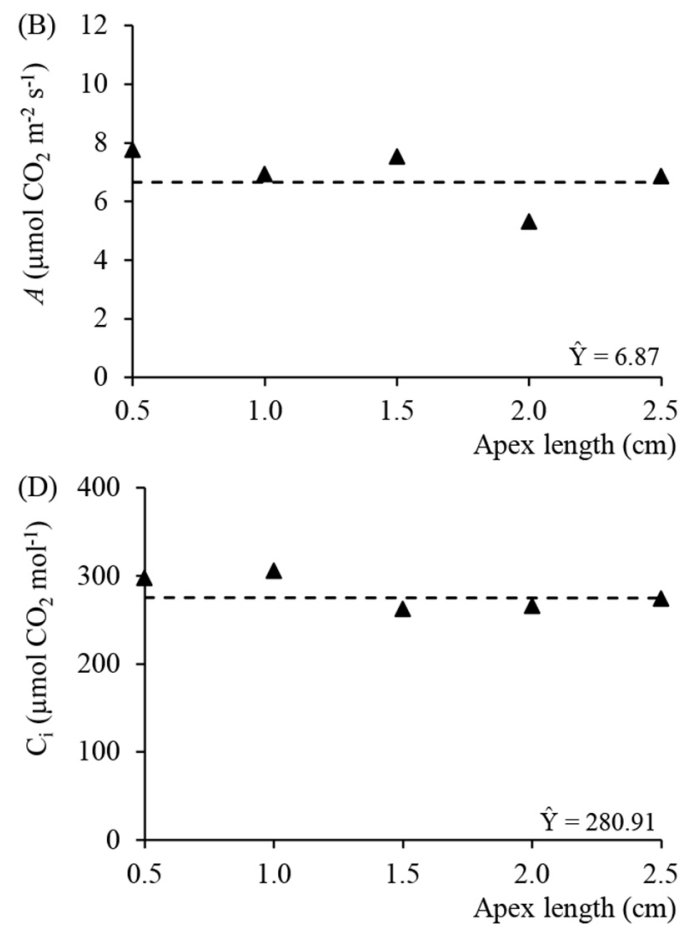

Figure 5: Chlorophyll content $(A)$, net assimilation rate of $\mathrm{CO}_{2}(B)$, transpiration rate $(C)$ and intercellular concentration of $\mathrm{CO}_{2}$ (D) of clonal plantlets of Conilon coffee produced using stem cuttings, at 120 days of cultivation, as a function of the length of the apex of the stem cutting, produced in Marilância-ES ("regression coefficient is significant, at $5 \%$ of probability, by the t-test). 
For the success of coffee crops, one of the critical points is the use of high-quality plantlets, as they contribute to the faster and more vigorous development of the plantation (Fonseca et al., 2019). Studies like this are of fundamental importance since they contribute to a better understanding of the factors that can limit the growth and quality of clonal plantlets of Conilon coffee.

In this study, apexes with lengths ranging from 0.5 to $2.5 \mathrm{~cm}$ were considered. Adding to the length of the base (4.0 $\mathrm{cm})$, the total lengths ranged from 4.5 to $6.5 \mathrm{~cm}$. In this way, the short apex favors the reduced total size, just as the long apex favors an excessive total length. Overall, the growth analyses show that the length of the apex does not effect most part of the variables, being only possible to observe gains for leaf area and biomass accumulation for cutting with 1.53 and $1.61 \mathrm{~cm}$ respectively, with no effect over the final quality of the plantlets.

\section{CONCLUSIONS}

The biomass accumulation of the plantlets of Conilon coffee produced by stem cutting may be favored by the use of bevel cut on the apex.

The length of the remaining apex does not seem to have a expressive effect over the quality or growth of the plantlets, being only possible to observe effects for leaf area and biomass accumulation.

\section{REFERENCES}

ALBIERO, A. L. M. et al. Morfoanatomia dos órgãos vegetativos de Piper crassinervium H.B. \& K. (Piperaceae). Acta Botanica Brasilica, 19(2):305-312, 2005.

AQUINO, L. P. et al. Cortes basais e substratos na formação de mudas clonais de cafeeiro canéfora. Coffee Science, 12(1):9-16, 2017.

BARROS, R. S. et al. Determination of leafarea of coffee (Coffea arabica L. cv. 'Bourbon Amarelo'). Revista Ceres, 20(107):44-52, 1973.

BELAN, L. L. et al. Aspectos fisiológicos do cafeeiro conilon: uma abordagem sistemática. Nucleus, 8(1):1-16, 2011.

BERNARDES, T. et al. Diagnóstico físico-ambiental da cafeicultura no Estado de Minas Gerais-Brasil. Coffee Science, 7(2):139-151, 2012.

BLITTERSDORFF, R.; KRANZ, J. Comparative studies on Fusarium xylarioides Steyaert (Gibberella xylarioides Heim et Saccas) the cause of the coffee tracheomycosis.
Journal of Plant Diseases and Protection, 83(9):529544, 1976.

BOOTH, C; WATERSTON, J. M. Gibberella xylarioides. In: CMI - Commonwealth Mycological Institute. Descriptions of pathogenic fungi and bactéria. Wallingford: CAB International, p.24, 1964.

BRAGA, M. F. et al. Enraizamento de estacas de três espécies silvestres de Passiflora. Revista Brasileira de Fruticultura, 28(2):284-288, 2006.

BRAGANÇA, S. M. et al. Formação de mudas. In:. Manual técnico para a cultura do café no Estado do Espírito Santo. Vitória: Secretaria de Estado de Agricultura, p.1928, 1995.

BRINATE, S. V. B. et al. Applicability of the method of linear dimensions to estimate leaf area in improved genotypes of Coffea arabica and Coffea canephora. American Journal of Plant Sciences, 6(5):651-658, 2015.

CARVALHO, A.; FAZUOLI, L. C. Café. In: FURLANI, A. M. C.; VIÉGAS, G. P. O melhoramento de plantas no instituto agronômico. Campinas: Instituto Agronômico, v.1, p.29-76, 1993.

CARVALHO, A. et al. Aspectos genéticos do cafeeiro. Revista Brasileira de Genética, 14(1):135-183. 1991.

CARVALHO, L. M. D. et al. Aspectos morfofisiológicos das cultivares de cafeeiro Catuaí-Vermelho e Conilon. Pesquisa Agropecuária Brasileira, 36(3):411416, 2001.

CONAGIN, C. H. T. M.; MENDES, A. J. T. Pesquisas citológicas e genéticas em três especies de Coffea: auto-incompatibilidade em Coffea canephora Pierre ex Froehner. Bragantia, 20(34):787-804, 1961.

COVRE, A. M. et al. Crescimento e desenvolvimento inicial de genótipos de café conilon. Revista Agro@ambiente On-line, 7(2):193-202, 2013.

DARDENGO, M. C. J. et al. Crescimento e qualidade de mudas de café conilon produzidas em diferentes recipientes e níveis de sombreamento. Coffee Science, 8(4):500-509, 2013.

DICKSON, A.; LEAF, A. L.; HOSNER, J. F. Quality appraisal of white spruce and white pine seedling stock in nurseries. Forest Chronicle, 36(1):10-13, 1960.

ESPINDULA, M. C.; PARTELLI, F. L. Vantagens do uso de clones no cultivo de cafeeiros canephora (Conilon e Robusta). Porto Velho, RO: Embrapa Rondônia. 2011, 16p. (Embrapa Rondônia: Documentos, 144). 
FERRÃO, M. A. G. et al. Origem, dispersão geográfica, taxonomia e diversidade genética de Coffea canephora. In: FERRÃO, R. G. et al. (Ed.) Café conilon. Vitória: Incaper, p.66-91, 2007.

FERRÃO, R. G. et al. Conilon Coffee, $3^{\text {rd }}$ editionupdated and expand ed. Vitória, ES: Incaper, 2019. 974p.

FERRÃO, R. G. et al. Café conilon: Técnicas de produção com variedades melhoradas. 4. ed. revisada e ampliada. Vitória, ES: Incaper, 2012. 74p.

FERREIRA, D. F. SISVAR: a computer statistical analysis system. Ciência e Agrotecnologia. 35(6):1039-1042, 2011.

FONSECA, A. F. A. et al. Jardins clonais de café conilon: técnicas para formação e condução. 2. ed. Vitória, ES: (Incaper: Circular Técnica, 04-I). Incaper, 2005. 56p.

FONSECA, A. F. A. et al. Clonal gardens, seed production and Conilon coffee seedling. In: FERRÃO, R. G. et al. ConilonCoffee. $3^{\text {rd }}$ editionupdated and expand ed. Vitória, ES: Incaper, p.289-325, 2019.

LIMA, R. L. S. et al. Comprimento de estacas e parte do ramo na formação de mudas de aceroleira. Revista Brasileira de Fruticultura, 28(1):83-86, 2006.

MAURI, A. L. et al. Produção de mudas: clones e sementes. In: FONSECA, A. F. A.; SAKIYAMA, N. S.; BORÉM, A. (Eds.). Café conilon do plantio à colheita. Viçosa, MG: UFV, p.50-69, 2015.

PAIVA, R. F. et al. Comportamento de cultivares de cafeeiros C. arabica L. enxertados sobre cultivar 'Apoatã IAC 2258' (Coffea canephora). Ciência Rural, 42(7):155$1160,2012$.

PAIVA, R. N. et al. Comportamento agronômico de progênies de cafeeiro (Coffea arabica L.) em Varginha MG. Coffee Science, 5(1):49-58, 2010.
PARTELLI, F. L. et al. Root system distribution and yield of Conilon coffee propagated by seeds or cuttings. Pesquisa Agropecuária Brasileira, 49(5):349-355, 2014.

PAULINO, A. J.; MATIELLO, J. B.; PAULINI, A. E. Produção de mudas de café Conilon por estacas: instruções técnicas sobre a cultura de café no Brasil. Rio de Janeiro: IBC/GERCA, 1985. 12p.

PONTES FILHO, F. S. T. et al. Comprimento de estacas e concentrações de ácido indolbutírico (AIB) na propagação vegetativa de pitaia. Revista Ciência Agronômica, 45(4):788-793, 2014.

ROCHA, R. B. et al. Caracterização e uso da variabilidade genética de banco ativo de germoplasma de Coffea canephora Pierre ex Froehner. Coffee Science, 8(4):478485, 2014.

STEYAERT, R. L. Contribuition a L'Étude des parasites des végétaux du Congo Belge. Bulletín Society Royale Botanique Belgique, 2(30):11-49, 1948.

TAIZ, L.; ZEIGER, E. Fisiologia vegetal. 5. ed. Porto Alegre: Artmed, 2013. 954p.

VAN DER VOSSEN, H. A. M. Coffee selection and breeding. In: CLIFFORD, M. N.; WILSON, K. C. (Ed.) Coffee: botany, biochemistry and production of beans and beverage. London: Croom Helm Westport, 1985. p.48-96.

VERDIN FILHO, A. C. et al. Growth and quality of clonal plantlets of conilon coffee (Coffea canephora Pierre ex A. Froehner) influenced by types of cuttings. American Journal of Plant Sciences, 5(14):21482153,2014

VERDIN FILHO, A. C. et al. Quality of clonal plantlets of Coffea canephora Pierre ex A. Froehner produced using coffee husk in the substrate. African Journal of Agricultural Research, 13(50):2826-2835, 2018. 